\title{
PENGARUH LASER ACUPOINT TERHADAP ANSIETAS PADA LANSIA
}

\author{
Sari, Melani Kartika ${ }^{1}$, Hidayatullah, Maulana Rahmat ${ }^{2}$ \\ ${ }^{1}$ Stikes Karya Husada Kediri \\ ${ }^{2}$ Stikes Pamenang \\ *Korespondensi penulis: melastarte@gmail.com
}

\begin{abstract}
Background: Anxiety is a psychological problem that often occurs in the elderly. Anxiety is a feeling of worry whose object is biased or unclear towards something that is not certain. This is often related to the various physical, social, and economic changes that occur in the elderly due to the aging process. Laser acupoint is an alternative intervention developed from acupuncture and acupressure using low-energy laser light which aims to balance body energy and homeostasis. Purpose: The aims of this study was to analyze the effect of laser acupoint on anxiety in the elderly. Methods: This type of research is pre-experimental, one group pre-post test design with a total sample of 26 respondents. Data were collected using the Geriatric Anxiety Inventory (GAI). The points used on the Laser Acupoint are He Ku (Li. 4), Sen Men (HT.7), Tai Chong (LR.3) and Sing Cien (LR. 2). The intervention was carried out for 20 minutes, with a frequency of 2 times a week, and carried out for 6 times of therapy. Data analysis used the Wilcoxon sign rank test. Result: the result of $p=0.00$ with a confidence level of 95\%. This shows the effect of laser acupoint on anxiety in the elderly. Conclusion: Acupoint laser can be used as an alternative intervention in overcoming anxiety in the elderly.
\end{abstract}

Keywords: Laser acupoint; Anxiety; Elderly

\begin{abstract}
ABSTRAK
Latar Belakang: Ansietas merupakan masalah psikologis yang sering terjadi pada lansia. Ansietas merupakan perasan khawatir yang objeknya bias atau tidak jelas terhadap sesuatu yang belum pasti. Hal ini sering berkaitan dengan terjadinya berbagai perubahan fisik, sosial, dan ekonomi yang terjadi pada lansia akibat proses penuaan. Laser acupoint merupakan intervensi alternatif yang dikembangkan dari akupunctur dan acupressure dengan menggunakan sinar laser berenergi rendah yang bertujuan untuk menyeimbangkan energi tubuh dan homeostasis. Tujuan: Tujuan penelitian ini yaitu menganalisis efek laser acupoint terhadap ansietas pada lansia. Metode: Jenis penelitian ini adalah Pra Eksperiment, one group pre-post test design dengan jumlah sampel sebanyak 26 responden. Data dikumpulkan menggunakan Geriatric Anxiety Inventory (GAI). Titik yang digunakan pada Laser Acupoint yaitu $\mathrm{He} \mathrm{Ku} \mathrm{(} \mathrm{Li}$. 4), Sen Men (HT.7), Tai Chong (LR.3) dan Sing Cien ( LR. 2). Intervensi dilakukan selama 20 menit, dengan frekuensi 2 kali dalam satu minggu, dan dilakukan selama 6 kali terapi.
\end{abstract}


Analisis data menggunakan Wilcoxon sign rank test. Hasil: hasil $\mathrm{p}=0,00$ dengan taraf kepercayaan 95\%. Hal ini menunjukkan adanya pengaruh laser acupoint terhadap ansietas pada lansia. Simpulan: Laser acupoint dapat digunakan sebagai salah satu intervensi alternatif dalam mengatasi ansietas pada lansia.

\section{Kata kunci: Laser acupoint; Ansietas; Lansia}

\section{PENDAHULUAN}

Lanjut usia merupakan fase akhir dalam tahap perkembangan manusia (Afrizal,2018). Hal ini merupakan suatu proses alami yang pasti akan dialami oleh setiap individu. Berbagai perubahan fisiologis, sosial, ekonomi, berpotensi menimbulkan gangguan pada kesehatan fisik maupun mental. Salah satu masalah kesehatan mental yang sering muncul pada lansia adalah ansietas atau kecemasan (Annisa, 2016). Ansietas merupakan kekhawatiran yang tidak jelas dan bersifat menyebar atau bias, serta berkaitan dengan rasa tidak pasti dan tidak berdaya (Yusuf et al, 2015).

Angka kejadian ansietas pada lansia menurut Kretchy (2014) yang melakukan penelitian pada 400 lansia hipertensi, 56\% diantaranya mengalami ansietas. Sedangkan menurut Akhriansyah (2016) angka kejadian ansietas pada dewasa dan lansia di negara berkembang berkisar 50\%. Ansietas dipandang dari Traditional Chinese Medicine, dengan sudut pandang keseimbangan Yin dan Yang dan Lima Unsur merupakan suatu kondisi yang diakibatkan api hati membumbung. Kondisi ini disebut juga Kan-Huo yang disebabkan Yang-Se-hati. Ansietas terdiri dari beberapa aspek yaitu aspek fisik, aspek emosional, dan aspek kognitif. Aspek fisik mencakup rasa pusing, berkeringat dingin, rasa mual, perasaan berdebar dan lainnya. Sedangkan aspek emosional mencakup rasa takut dan panik. Aspek kognitif mencakup kebingungan dalam berpikir, gangguan pada memori, dan rasa bingung (Risnawati, 2014).

Intervensi alternatif merupakan tindakan penanganan pasien secara tradisional yang telah diakui dan dapat dilakukan sebagai pengganti intervensi konvensional, maupun dilakukan secara berdampingan dengan terapi medis (Hawks, 2012). Menurut Undang-Undang Keperawatan No.38 tahun 2014, tentang pengobatan alternatif pada pelayanan Kesehatan. Hal yang dimaksud adalah tindakan intervensi non konvensional 
yang bertujuan untuk meningkatkan derajat hidup masyarakat melalui upaya promotif, preventif, kuratif dan rehabilitatif serta didapat melalui pendidikan yang terstruktur, berkualitas dan memiliki keamanan dan efektivitas yang tinggi. Laser acupoint merupakan salah satu intervensi alternatif yang dikembangkan dari Traditional Chinese Medicine dengan menggunakan sinar laser berenergi rendah pada titik-titik meridian akupunktur. Intervensi ini bersifat tidak nyeri, tidak menyebabkan trauma atau kerusakan pada kulit, tidak menyebabkan infeksi, serta waktu terapi yang lebih singkat dibandingkan dengan akupunktur menggunakan jarum. Laser acupoint mampu membantu memberikan energi sehingga tercapai keseimbangan Yin dan Yang dan keseimbangan antar organ di dalam tubuh manusia (Kreisel, 2012)

Radiasi sinar laser memengaruhi sistem enzimatis dalam respirasi sel. Sinar diserap sesuai panjang gelombang oleh fotoreseptor primer lalu mengaktivasi mitokondria untuk mensintesis ATP serta menimbulkan perubahan muatan pada intra dan ekstra sel yang menyebabkan arus energi di sekitarnya (Saputra, 2014). Sinar laser dosis rendah mampu mengurangi nyeri inflamasi, meningkatkan penyembuhan luka, penyakit kronis, mengurangi nyeri neurogenic serta memperbaiki masalah saraf (L Navratil, 2012). Rangsangan pada titik-titik akupunktur dapat membantu menurunkan tingkat kecemasan (Lin, 2016).

\section{METODE}

Jenis penelitian ini merupakan pra eksperiment dengan one group pre-post test design. Penelitian ini dilakukan selama 1 bulan, pada bulan Oktober hingga November tahun 2018. Populasi penelitian ini adalah lansia yang mengalami kecemasan di wilayah kerja Puskesmas Papar, Kabupaten Kediri. Jumlah responden penelitian ini yaitu 26 lansia yang diambil menggunakan teknik pengambilan sampel Purposive Sampling. Kriteria Inklusi dalam penelitian ini yaitu lansia berusia 60 hingga 90 tahun yang mengalami kecemasan dan bersedia menjadi responden. Sedangkan kriteria eksklusi pada penelitian ini yaitu lansia yang pernah menjalani terapi laser acupoint, mengalami depresi dan gangguan kognitif berat. 
Intervensi laser acupoint dilakukan pada responden yang memenuhi kriteria inklusi selama 20 menit. Frekuensi intervensi yaitu 2 kali dalam satu minggu. Total pelaksanaan intervensi yaitu sebanyak 6x. Data diperoleh melalui kuesioner GAI (Geriatric Anxiety Inventory) yang terdiri dari 20 pertanyaan. Hasil penilaian kuesioner GAI terbagi menjadi empat kategori, skor 1-5 dikategorikan ansietas ringan, 6-10 dikategorikan ansietas sedang, 11-15 dikategorikan ansietas berat, dan skor 16-20 dikategorikan sebagai ansietas panik. Analisis data menggunakan uji Wilcoxon Sign Rank Test untuk mengetahui perbedaan tingkat ansietas sebelum dan sesudah intervensi laser acupoint.

Penelitian ini telah mendapatkan surat laik etik dari komite etik Stikes Karya Husada Kediri pada tanggal 12 September 2018 dengan nomor 155/EC/LPPM/STIKES/KH/IX/2018.

\section{HASIL}

Penelitian ini dilakukan pada lansia yang mengalami ansietas di wilayah kerja Puskesmas Papar.

Tabel 1. Karakteristik Responden

\begin{tabular}{llcc}
\hline & Karakteristik & Jumlah (n) & Presentase (\%) \\
\hline Jenis Kelamin & Pria & 12 & $46,15 \%$ \\
& Wanita & 14 & $53,85 \%$ \\
\hline Jumlah & & 26 & $100 \%$ \\
\hline Usia & $60-74$ thn & 19 & $73,07 \%$ \\
& 75-90 thn & 7 & $26,93 \%$ \\
\hline Jumlah & & 26 & $100 \%$ \\
\hline Pendidikan & Tidak Sekolah & 2 & $7,69 \%$ \\
& SD & 10 & $38,46 \%$ \\
& SMP & 9 & $34,62 \%$ \\
& SMA & 5 & $19,23 \%$ \\
\hline Jumlah & & 26 & $100 \%$ \\
\hline
\end{tabular}

Tabel 1 menunjukkan karakteristik responden penelitian yang sebagian besar berusia 60 hingga 74 tahun, berjenis kelamin wanita, dan tingkat pendidikan mayoritas adalah Sekolah Dasar (SD). 
Tabel 2 Tingkat Ansietas Lansia sebelum dan sesudah intervensi Laser Acupoint

\begin{tabular}{lcccc}
\hline Ansietas & \multicolumn{2}{c}{ Pretest } & \multicolumn{2}{c}{ Posttest } \\
\cline { 2 - 5 } & $\mathrm{F}$ & $\%$ & $\mathrm{~F}$ & $\%$ \\
\hline Ringan & 0 & & 4 & \\
Sedang & 10 & & 21 & \\
Berat & 16 & & 1 & \\
Panik & 0 & & 0 & \\
\hline
\end{tabular}

Wilcoxon Sign Rank Test $p=0,00$

Hasil analisis data menggunakan uji Wilcoxon Sign Rank Test menunjukkan $\mathrm{p}=0,00$, dengan mean pretest 2,615 dan mean posttest 1,88 . Hal ini menunjukkan adanya pengaruh intervensi Laser Acupoint terhadap ansietas pada lansia.

\section{PEMBAHASAN}

Hasil penelitian ini menunjukkan adanya pengaruh intervensi Laser Acupoint terhadap ansietas. Penurunan tingkat ansietas terbesar yaitu 7 dan terkecil 0. Dalam penelitian ini terdapat 7 responden yang secara kategori tidak menurun tingkat ansietasnya yaitu berada dalam kategori ansietas sedang dan berat, namun secara nominal terjadi penurunan skala ansietas dari skala 8 ke 6,9 ke 8,10 ke 7, 7 ke 6, 9 ke 5,10 ke 8 , dan 13 ke 12. Jadi secara kualitatif tetap terjadi penurunan skala ansietas meskipun secara kategorik masih berada di dalam tingkat ansietas yang sama. Hasil negative rank pada uji Wilcoxon Sign Rank Test=19. Hal ini menunjukkan nilai kelompok post test lebih rendah dari nilai kelompok pre test. Hal ini menguatkan bahwa terjadi penurunan ansietas yang bermakna pada responden setelah dilakukan intervensi laser acupoint.

Ansietas merupakan perasaan tidak nyaman, atau rasa takut terhadap hal yang bias, tidak spesifik, atau tidak diketahui oleh individu yang disertai respon (Williams, 2012). Perasaan khawatir membuat seseorang mengambil tindakan atau respon terhadap hal yang dianggap sebagai ancaman (Yusuf, 2015). Individu yang mengalami ansietas atau kecemasan akan mengalami berbagai perubahan pada tanda-tanda vital, mengalami gangguan pola makan, gangguan tidur dan ketegangan otot. Ketegangan otot terjadi sebagai respon tubuh yang waspada terhadap bahaya yang mengancam. 
Ditinjau dari ilmu Traditional China Medicine (TCM) tentang akupunctur, ansietas merupakan efek dari fungsi yang-hati yang berlebihan. Yang berlebih ini memengaruhi keempat organ Zang lainnya sehingga menimbulkan Yang se atau energi hati yang berlebihan. Laser acupoint yang bertujuan menurunkan ansietas ditujukan pada titik-titik meridian akupunctur tertentu. Titik akupuntur yang berfungsi menurunkan ansietas antara lain He Ku (Li. 4), Sen Men (HT.7), Tai Chong (LR.3) dan Sing Cien ( LR. 2) (Shariati, 2012).

Titik He Ku dan Sen Men merupakan titik yang berfungsi untuk menenangkan jantung, menghilangkan api, menjernihkan aliran panas jantung, menyegarkan sirkulasi darah, dan mengatur perputaran atau peredaran energi di dalam tubuh. Sedangkan titik Tai Chong dan Sing Cien memengaruhi saraf simpatis dan memberikan efek vasodilator. Titik ini juga memiliki manfaat mengurangi panas pada darah, menentramkan angin, dan mengurangi panas hati (Lin, 2016).

Laser acupoint mampu memengaruhi titik-titik yang berpengaruh pada ansietas. Suasana hati dan ansietas dianggap sebagai tanda dan gejala gangguan aliran energi (Pilkington, 2013). Melakukan laser acupoint pada beberapa titik tertentu dapat berpengaruh pengaruh pada penurunan depresi dan stres (Pilkington, 2013). Laser acupoint merupakan modalitas akupunktur yang lebih disukai untuk populasi tertentu seperti lansia dan balita karena tidak invasif, bebas dari rasa sakit, dan memiliki kemungkinan efek samping yang sedikit (Chon, 2019).

Berdasarkan teori Traditional Chinese Medicine dan psikoneuroimunologi, pemberian intervensi Laser Acupoint pada lansia dapat menurunkan sekresi norepinefrin. Hal ini memberikan pengaruh pada penurunan kecemasan, serta penurunan tekanan darah. Stimulasi pada titik meridian akupuntur yang berhubungan dengan hati menggunakan sinar laser juga dapat menenangkan hati yang kelebihan energi dan menyeimbangkan energi di dalam tubuh sehingga ansietas dapat menurun. Selain itu, stimulasi pada titik tersebut juga dapat memperlancar sirkulasi darah (Chon, 2019).

\section{SIMPULAN DAN SARAN}


Laser Acupoint dapat menurunkan tingkat ansietas pada lansia. Titik meridian akupunktur yang digunakan yaitu $\mathrm{He} \mathrm{Ku}$ (Li. 4), Sen Men (HT.7), Tai Chong (LR.3) dan Sing Cien ( LR. 2). Laser Acupoint dapat digunakan sebagai intervensi alternatif beragam masalah Kesehatan lain yang terjadi pada lansia.

\section{DAFTAR PUSTAKA}

Afrizal. (2018). Permasalahan Yang Dialami Lansia Dalam Menyesuaikan Diri Terhadap Penguasaan Tugas-Tugas Perkembangannya. Jurnal Bimbingan dan Konseling Islam. 2(2). 92-103.

Akhriansyah. (2016). Pengaruh Progressive Muscle Relaxation terhadap Perubahan Ansietas, Insomnia dan Kemampuan Relaksasi di PSTW Kabupaten Bungo. Program Studi S2 Keperawatan Universitas Andalas.

Annisa, DF. (2016). Konsep Kecemasan (Anxiety) pada Lansia. Jurnal Konselor. 5 (2). 93-99.

Chon. (2019). Laser Acupuncture: A Concise Review. Medical Acupuncture. 31 (3). 164-168

Hawks, J. (2012). CAM: Definition and Clasification Overview. Urologic Nursing. 23 (3). 221-223.

Kreisel V \& Weber M (2012). A Practical Book of Acupuncture. $1^{\text {st }}$ ed. Berlin: Fuchtenbusch

Kretchy, IA. (2014). Mental Health in Hypertentions: Assessing system of anxiety, depressions and stress on anty hypertension adherence. International Journal of Mental Health System. 8 (1). 25-29.

L Navratil. (2012). Containdication in Noninvasive laser therapy: truth and fiction. J.Clin Laser Med Surgery. 20 (6). 341-343.

Lin, G. (2016). Effectiveness of Acupressure on the Taichong Acupoint in Lowering Blood Pressure ini Patients with Hypertention: A Randomized Clinical Trial. Evidence Based Complementary and Alternative Medicine. 21 (16). 1-9.

Risnawati, R. (2014). dalam Annisa (2016). Konsep Kecemasan pada Lansia. Jurnal Konselor. 5 (2). 93-95

Saputra, K. (2014). Laser Acupuncture. Surabaya: Airlangga University Press. 
Shariati, A. (2012). The Effect of Accupressure on Sleep Quality in Hemodialysis Patients. Complementary Therapies in Medicine. 20 (6). 417-423.

Singh. (2016). Mental and Spiritual Health and Heart: A Viewpoint. World Heart Journal. 8 (3). 233-236.

Pilkington, K. (2013). Neurobiology of Acupuncture. International Review of Biology. https://www.sciencedirect.com/topics/pharmacology-toxicology-andpharmaceutical-science/laser-acupuncture

Yusuf, A. (2015). Buku Ajar Keperawatan Jiwa. Surabaya: Universitas Airlangga. 